Australian Journal of

Crop Science

AJCS

AJCS 13(09):1552-1560 (2019)

ISSN:1835-2707

doi: 10.21475/ajcs.19.13.09.p1919

\title{
Salt effect of potassium fertilizer on productivity and technological quality of sugarcane
}

\author{
Igor Tenório Marinho da Rocha ${ }^{1}$, Fernando José Freire ${ }^{{ }^{1}}$, Emídio Cantídio Almeida de Oliveira ${ }^{1}$, Edivan \\ Rodrigues de Souza ${ }^{1}$, Maria Betânia Galvão dos Santos Freire ${ }^{1}$, Djalma Euzébio Simões Neto ${ }^{2}$, Aníbia Vicente \\ da Silva ${ }^{1}$
}

\author{
${ }^{1}$ Agronomy Department, Federal Rural University of Pernambuco, street Dom Manoel de Medeiros, $s / n$, Dois \\ Irmãos, Recife, CEP 52171-900, Pernambuco, Brazil \\ ${ }^{2}$ Experimental Station of Sugarcane, street Ângela Cristina Canto Pessoa de Luna, s/n, Santa Terezinha, \\ Carpina, CEP 55812-010, Pernambuco, Brazil
}

\section{*Corresponding author: fernandojfreire@uol.com.br}

\begin{abstract}
The $\mathrm{K}$ is important for sugar concentration in sugarcane, but the salt effect on $\mathrm{K}$ fertilizer may reduce the productivity. The objective of this study was to evaluate productivity of sugarcane, to establish soil and plant $K$ critical levels, and to determine a saline limit of the soil with maximum agronomic efficiency. The sugarcane variety RB992506 was cultivated in the field in Oxisol (Kandic) dystrophic with very sandy and low $\mathrm{K}$ content, mainly in subsurface. Six doses of $\mathrm{K}_{2} \mathrm{O}$ were used: $0 ; 25 ; 50 ; 100 ; 200 ; 250 \mathrm{~kg} \mathrm{ha}^{-1}$. We evaluated soil and leaf $\mathrm{K}$ content, electrical conductivity of the saturated soil paste, productivity and technological quality of the sugarcane. The application of $K$ promoted increase in soil and leaf $\mathrm{K}$ levels, increasing also both productivity and the sugar concentration. The dose of maximum agronomic efficiency was $150 \mathrm{~kg} \mathrm{ha}^{-1}$ of $\mathrm{K}_{2} \mathrm{O}$ and production of $116 \mathrm{Mg} \mathrm{ha}{ }^{-1}$. High doses of $\mathrm{K}\left(>200 \mathrm{~kg} \mathrm{ha}^{-1}\right.$ of $\left.\mathrm{K}_{2} \mathrm{O}\right)$ decreased the productivity due to elevated soil salinity by the application of $K$ fertilizer. The critical levels of $K$ were $0.18 \mathrm{cmol}_{\mathrm{c}} \mathrm{dm}^{-3}$ in the soil and 9.53 $\mathrm{g} \mathrm{kg}^{-1}$ in the plant and were associated with low doses of $\mathrm{K}\left(<25 \mathrm{~kg} \mathrm{ha}^{-1}\right.$ of $\left.\mathrm{K}_{2} \mathrm{O}\right)$. The salinity limits that reduced productivity were 1.38

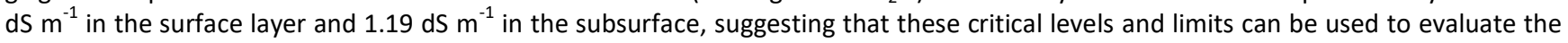
fertility of sandy soils cultivated with sugarcane in tropical regions.
\end{abstract}

Keywords: K fertilization; K critical level; sugar concentration; soil salinity. Abbreviation: EC_Electrical conductivity; TRS_Total recoverable sugars.

Introduction

Sugarcane's demand for $\mathrm{K}$ is very high, extracting up to $400 \mathrm{~kg}$ $\mathrm{ha}^{-1}$ of $\mathrm{K}$ from the soil (Pancelli et al., 2015). K participates in the plant's biophysical and biochemical processes, such as stomatal opening and closing and promotion of cellular turgor. $K$ serves as an activator for more than 40 enzymatic complexes, acts on the metabolisms of proteins and carbohydrates, transports photoassimilates and serves as an osmoregulator (Zörb et al., 2014).

Most Brazilian soils utilized for sugarcane production, such as Ultisols and Oxisols, are not rich in $\mathrm{K}$ due to the high degree of weathering and the source material (Bordonal et al., 2018). In addition, $\mathrm{K}$ uptake by the crop is high, emphasizing the need to study sugarcane's demand for the nutrient in different edaphoclimatic conditions of cultivation.

Some studies have been carried out to improve the diagnosis and recommendation of $K$ fertilization for sugarcane (Uchôa et al., 2009; Schultz et al., 2010). However, in addition to the soil type, the intrinsic characteristics of different varieties of sugarcane can also promote differing responses to fertilization (Otto et al., 2010; Almeida et al., 2015).

Uchôa et al. (2009) evaluated increased productivity of six sugarcane varieties as a function of the $\mathrm{K}$ application and observed that the doses of 94 and $165 \mathrm{~kg} \mathrm{ha}^{-1}$ of $\mathrm{K}_{2} \mathrm{O}$ caused maximum efficiency. In a similar study, Otto et al. (2010) observed that the dose of $\mathrm{K}_{2} \mathrm{O}$ of maximum agronomic efficiency was $150 \mathrm{~kg} \mathrm{ha}^{-1}$ which was responsible for the production of $160 \mathrm{Mg} \mathrm{ha}^{-1}$ of sugarcane. Schultz et al. (2010) also observed higher productivity of sugarcane when fertilized with $120 \mathrm{~kg} \mathrm{ha}^{-1}$ of $\mathrm{K}_{2} \mathrm{O}$ in combination with $80 \mathrm{~kg} \mathrm{ha}^{-1}$ of $\mathrm{N}$. Fertilizer salinity attributed to these high doses of $\mathrm{K}$ may limit sugarcane productivity and establish varied critical levels of $\mathrm{K}$ in the soil, as described in literature (Orlando Filho et al., 1981; Chalita, 1991; Cavalcanti et al., 2008). 
Thus, there are several suggestions of critical levels of $\mathrm{K}$ for sugarcane. Orlando Filho et al. (1981) suggested a critical level of $0.23 \mathrm{cmol}_{\mathrm{c}} \mathrm{dm}^{-3}$. Chalita (1991) suggested $0.15 \mathrm{cmol}_{\mathrm{c}} \mathrm{dm}^{-3}$ for first-cycle sugarcane (cane-plant) and $0.12 \mathrm{cmol}_{\mathrm{c}} \mathrm{dm}^{-3}$ from the second-cycle onwards (ratoon-cane). Some regional manuals, such as the Manual of Fertilization Recommendations for the State of Pernambuco suggest 0.15 $\mathrm{cmol}_{\mathrm{c}} \mathrm{dm}^{-3}$ (Cavalcanti et al., 2008).

The decrease in productivity when using increasing amounts of fertilizers is primarily caused by the toxicity of nutrients and the increase of soil salinity in the plant's rhizosphere. The toxicity caused by $\mathrm{K}$ is controversial in literature, widely from full toxicity (Anschütz et al., 2014) to non-toxic effect of $\mathrm{K}$ (Ahmad and Maathuis, 2014).

The clay content of the soil combined with the salt effect of the $\mathrm{K}$ fertilizer may also be responsible for this variation in the critical levels. McLean (1976) reported that the sufficiency levels of exchangeable $\mathrm{K}$ should vary with the soil cation exchange capacity (CEC), but not merely as a simple percentage of the CEC. Moreover, the relationship between $\mathrm{K}$ content and soil in practice is complicated by factors such as leaching of $\mathrm{K}$ from sandy textured soils, and fixation of added $K$, release of native $K$ from, non-exchangeable forms in the soils with high clay content.

Large portion of the sugarcane cultivation in the Northeast of Brazil is carried out in highly sandy soils, influencing the critical levels of $\mathrm{K}$. The critical levels have been suggested by the manuals of fertilization and recommendations which are highly generic. Additionally, the studies that established these critical levels are out-of-date. Newer technologies and crop management techniques have been implemented in the field of sugarcane production, such as the use of residual byproducts from the sugar and ethanol industries themselves. This directly impacts $K$ nutrition and makes it essential to update $\mathrm{K}$ fertilization studies to aggregate knowledge and improve crop productivity.

In addition to agricultural productivity, great attention has been paid to $\mathrm{K}$ due to its metabolic and transportation functions for carbohydrates (Zörb et al., 2014). It is postulated that higher $\mathrm{K}$ supply promotes greater accumulation of sucrose in the sugarcane juice, as observed by Ashraf et al. (2009). However, other studies have found no effect for $\mathrm{K}$ nutrition on the accumulation of sucrose (Almeida et al., 2015).

Thus, there is a further need to investigate technological quality in plants with a high supply of $\mathrm{K}$, making it is possible to better establish critical levels for this important production variable. Payments received by the farmers for raw sugarcane sold for industrial processing is determined according to sugar content rather than culm weight. As the physiological functions of $\mathrm{K}$ directly contribute to sugar production, greater understanding of these processes is fundamental both to the farmers as well as the sugarcane industry.

However, increasing in agricultural productivity may be limited by the salt effect of $\mathrm{K}$ fertilizer, especially in sandy soils with limited $\mathrm{K}$ availability, such as some soils cultivated with sugarcane in Brazil, China, India, and Thailand (Food and Agriculture Organization, 2012), which require high fertilization. It is crucial to establish the critical levels of $K$ in these environments to maximize yields up to the limit of the salt effect of the fertilizer.

The novelty of this study was to associate the doses of maximum agronomic and economic efficiency of $\mathrm{K}$ for sugarcane cultivation in sandy soils to the saline effect of the fertilizer, which may allow the farmer to divide these doses when the recommendations of $\mathrm{K}$ are very high. Thus, the objective of this work was to evaluate productivity and the technological quality of sugarcane to establish soil and plant $K$ critical levels, and to determine a saline limit of the soil with maximum agronomic efficiency for $\mathrm{K}$ utilization.

\section{Results and discussion}

\section{$K$ content in soil and sugarcane as a function of $K$ applied to} the soil

The $\mathrm{K}$ content in the soil layers of $0.0-0.25 \mathrm{~m}$ and $0.25-0.50 \mathrm{~m}$ was increased linearly as function of amounts of $\mathrm{K}$ applied (Figure 1). The increase in $\mathrm{K}$ content in the subsurface layer was higher than in the surface layer. The availability of $\mathrm{K}$ was increased in depth and was similar in the soil profile up to 50 $\mathrm{cm}$ depth from the application of $50 \mathrm{~kg} \mathrm{ha}^{-1}$ of $\mathrm{K}_{2} \mathrm{O}$ (Figure 1A). Some reports from previous studies have also shown changes in the $\mathrm{K}$ levels of the soil due to the $\mathrm{K}$ application (Otto et al., 2010). The high sandy texture of both soil layers in our study has facilitated $\mathrm{K}$ extraction.

The $\mathrm{K}$ content in the leaf also increased linearly with the increase of $\mathrm{K}$ applied (Figure 1B), as has been reported in the literature (Uchôa et al., 2009; Otto et al., 2010). The increase in $\mathrm{K}$ content in the leaf was $13 \%$ between the control treatment and the highest dose of $\mathrm{K}$ applied. Usually this increment is curvilinear. This curvilinear effect was not observed in our study because "luxury consumption" of $\mathrm{K}$ occurred, making determination of maximum content in leaf difficult by $K$ application.

The relationship between increasing amount of a nutrient applied to the soil and the content in the leaf should be curvilinear quadratic (Sousa et al., 2018). The tendency of this relationship is to reach a plateau. When the content is extremely high in leaf there may be reduction of growth of the plant by the toxic effect of the nutrient. The quantities applied of $\mathrm{K}$ in our study did not cause these effects. The plateau was not reached and there was no reduction of growth by toxicity. $\mathrm{K}$ was stored in vacuoles as a nutritional reserve of plants (Mengel and Kirkby, 2001). This is a common metabolic strategy when soil $\mathrm{K}$ availability is high (Ahmad and Maathuis, 2014), especially in sandy soils, where nutrient absorption is higher when there are no water restrictions.

\section{Agricultural productivity and technological quality of the sugarcane as a function of $K$ applied to the soil}

The application of $\mathrm{K}$ promoted an increasing quadratic effect on the agricultural productivity of sugarcane and linear effect in the sugar concentration (Figure 2). The dose which caused greatest yield increase was $150 \mathrm{~kg} \mathrm{ha}^{-1} \mathrm{~K}_{2} \mathrm{O}$, which increased productivity to $116 \mathrm{Mg} \mathrm{ha}^{-1}$, whereas treatment without additional $\mathrm{K}$ resulted in a yield of $102 \mathrm{Mg} \mathrm{ha}^{-1}$. The $14 \mathrm{Mg} \mathrm{ha}^{-1}$ 
Table 1. Chemical and physical soil attributes at different depths before the field trial at the municipality of Caaporã, Paraíba, Brazil

\begin{tabular}{|c|c|c|}
\hline \multirow{2}{*}{ Attribute } & \multicolumn{2}{|c|}{ Depth (m) } \\
\hline & $0.0-0.25$ & $0.25-0.50$ \\
\hline $\mathrm{pH}_{\text {water }}(1: 2.5)$ & 4.70 & 4.40 \\
\hline$P\left(\mathrm{mg} \mathrm{dm}^{-3}\right)$ & 8.00 & 2.10 \\
\hline $\mathrm{Na}^{+}\left(\mathrm{cmol}_{\mathrm{c}} \mathrm{dm}^{-3}\right)$ & 0.20 & 0.10 \\
\hline $\mathrm{K}^{+}\left(\mathrm{cmol}_{\mathrm{c}} \mathrm{dm}^{-3}\right)$ & 0.16 & 0.04 \\
\hline $\mathrm{Ca}^{2+}\left(\mathrm{cmol}_{\mathrm{c}} \mathrm{dm}^{-3}\right)$ & 1.58 & 1.20 \\
\hline $\mathrm{Mg}^{2+}\left(\mathrm{cmol}_{\mathrm{c}} \mathrm{dm}^{-3}\right)$ & 0.50 & 0.40 \\
\hline $\mathrm{Al}^{3+}\left(\mathrm{cmol}_{\mathrm{c}} \mathrm{dm}^{-3}\right)$ & 0.20 & 0.20 \\
\hline$(\mathrm{H}+\mathrm{Al})\left(\mathrm{cmol}_{\mathrm{c}} \mathrm{dm}^{-3}\right)$ & 2.30 & 1.90 \\
\hline $\mathrm{CEC}_{\text {effective }}\left(\mathrm{cmol}_{\mathrm{c}} \mathrm{dm}^{-3}\right)^{(1)}$ & 2.40 & 1.70 \\
\hline $\mathrm{CEC}_{\text {potential }}\left(\mathrm{cmol}_{\mathrm{C}} \mathrm{dm}^{-3}\right)^{(2)}$ & 4.50 & 3.40 \\
\hline$V(\%)^{(3)}$ & 48.40 & 44.50 \\
\hline$m(\%)^{(4)}$ & 8.50 & 11.60 \\
\hline $\mathrm{TOC}\left(\mathrm{g} \mathrm{kg}^{-1}\right)^{(5)}$ & 3.00 & 1.56 \\
\hline $\mathrm{Fe}\left(\mathrm{mg} \mathrm{dm}^{-3}\right)$ & 88.30 & 92.96 \\
\hline $\mathrm{Cu}\left(\mathrm{mg} \mathrm{dm}^{-3}\right)$ & 4.43 & 1.93 \\
\hline $\mathrm{Zn}\left(\mathrm{mg} \mathrm{dm} \mathrm{m}^{-3}\right)$ & 1.25 & 1.93 \\
\hline $\mathrm{Mn}\left(\mathrm{mg} \mathrm{dm} \mathrm{m}^{-3}\right)$ & 5.09 & 1.93 \\
\hline Sand $\left(\mathrm{g} \mathrm{kg}^{-1}\right)$ & 850 & 730 \\
\hline Silt $\left(\mathrm{g} \mathrm{kg}^{-1}\right)$ & 30 & 110 \\
\hline Clay $\left(\mathrm{g} \mathrm{kg}^{-1}\right)$ & 120 & 160 \\
\hline Textural class & Sandy & Sandy \\
\hline $\operatorname{Ds}\left(\mathrm{Mg} \mathrm{m}^{-3}\right)^{(6)}$ & 1.32 & 1.68 \\
\hline $\mathrm{Dp}\left(\mathrm{Mg} \mathrm{m}^{-3}\right)^{(7)}$ & 2.82 & 2.73 \\
\hline $\operatorname{Pt}(\%)^{(8)}$ & 53.05 & 38.29 \\
\hline
\end{tabular}

${ }^{(1)}$ Effective cation exchange capacity; ${ }^{(2)}$ Potential cation exchange capacity; ${ }^{(3)}$ Saturation by bases; ${ }^{(4)}$ Saturation by aluminum; ${ }^{(5)}$ Total organic carbon; ${ }^{(6)}$ Bulk density; ${ }^{\left({ }^{(7)}\right.}$ Particles density; ${ }^{(8)}$ Total Porosity.

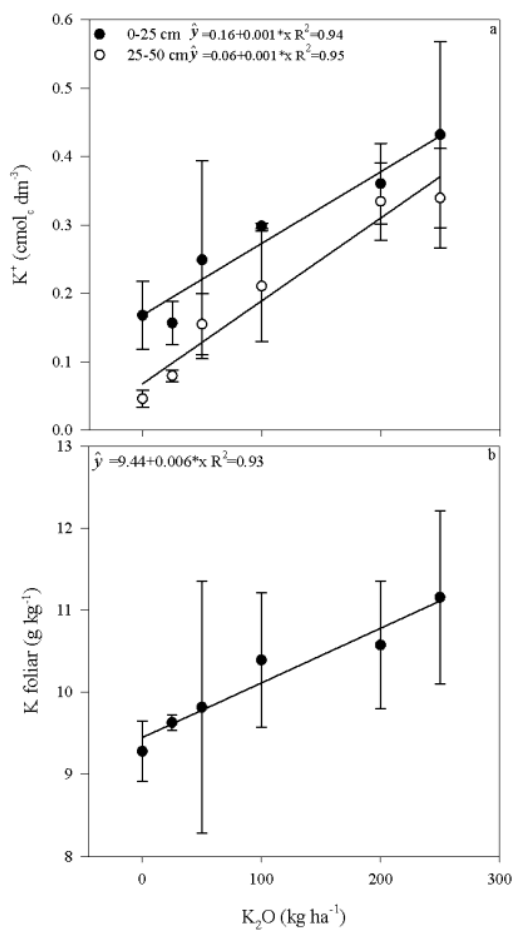

Fig 1. Potassium content in soil at depths $(0-25 \mathrm{~cm})$ and $(25-50 \mathrm{~cm})(\mathrm{a})$ and potassium content in sugarcane leaf $(\mathrm{b})$ as a function of potassium applied to the soil. 


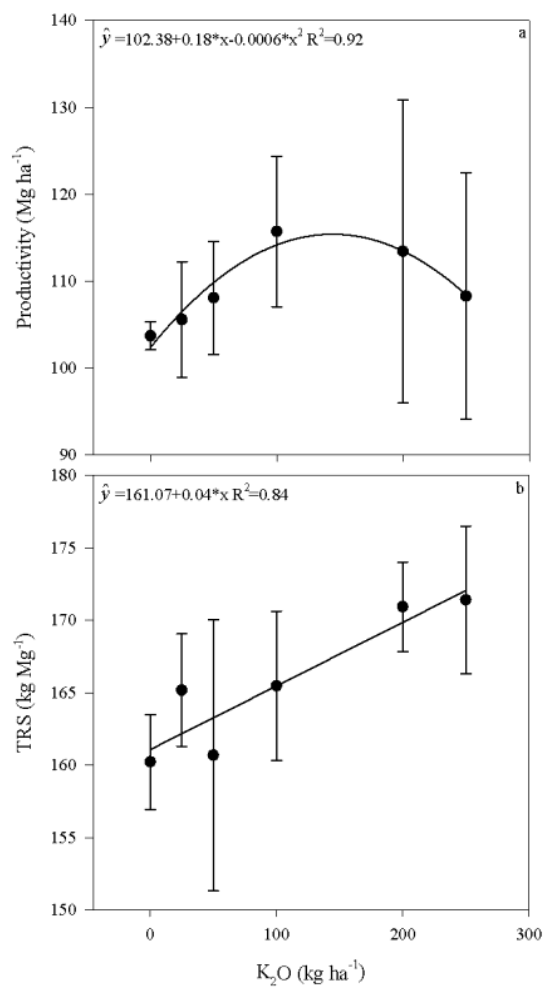

Fig 2. Agricultural productivity (a) and total recoverable sugar (TRS) (b) of sugarcane as a function of potassium applied to the soil.

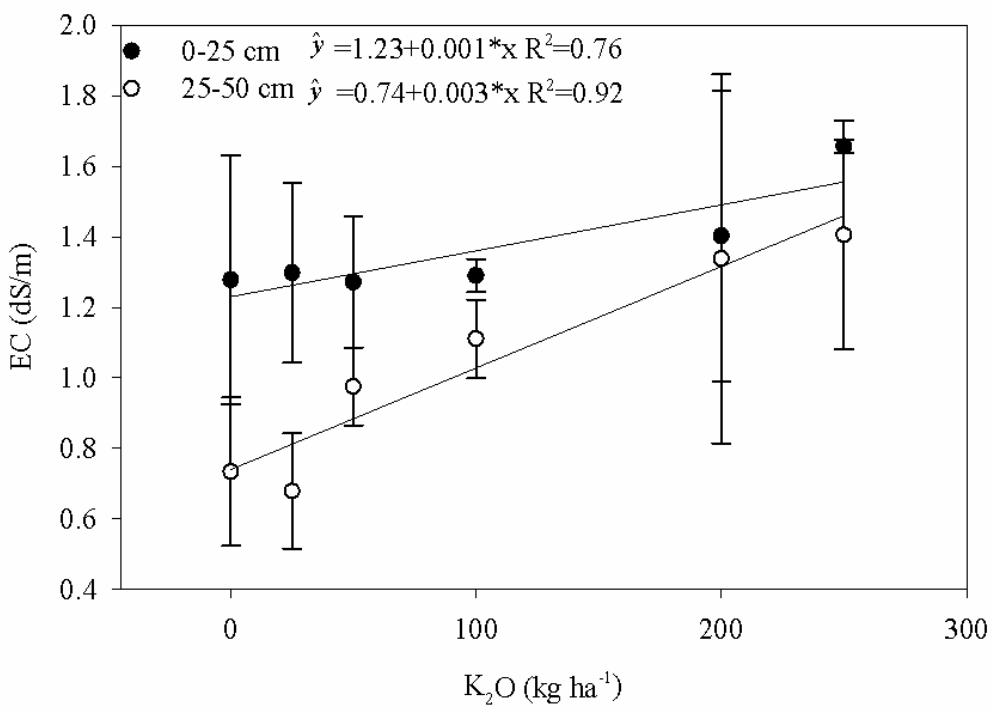

Fig 3. Electric conductivity $(E C)$ of the saturated paste at depths $(0-25 \mathrm{~cm})$ and $(25-50 \mathrm{~cm})$ as a function of the potassium applied to the soil. 
$\mathrm{K}$ foliar $\left(\mathrm{g} \mathrm{kg}^{-1}\right)$

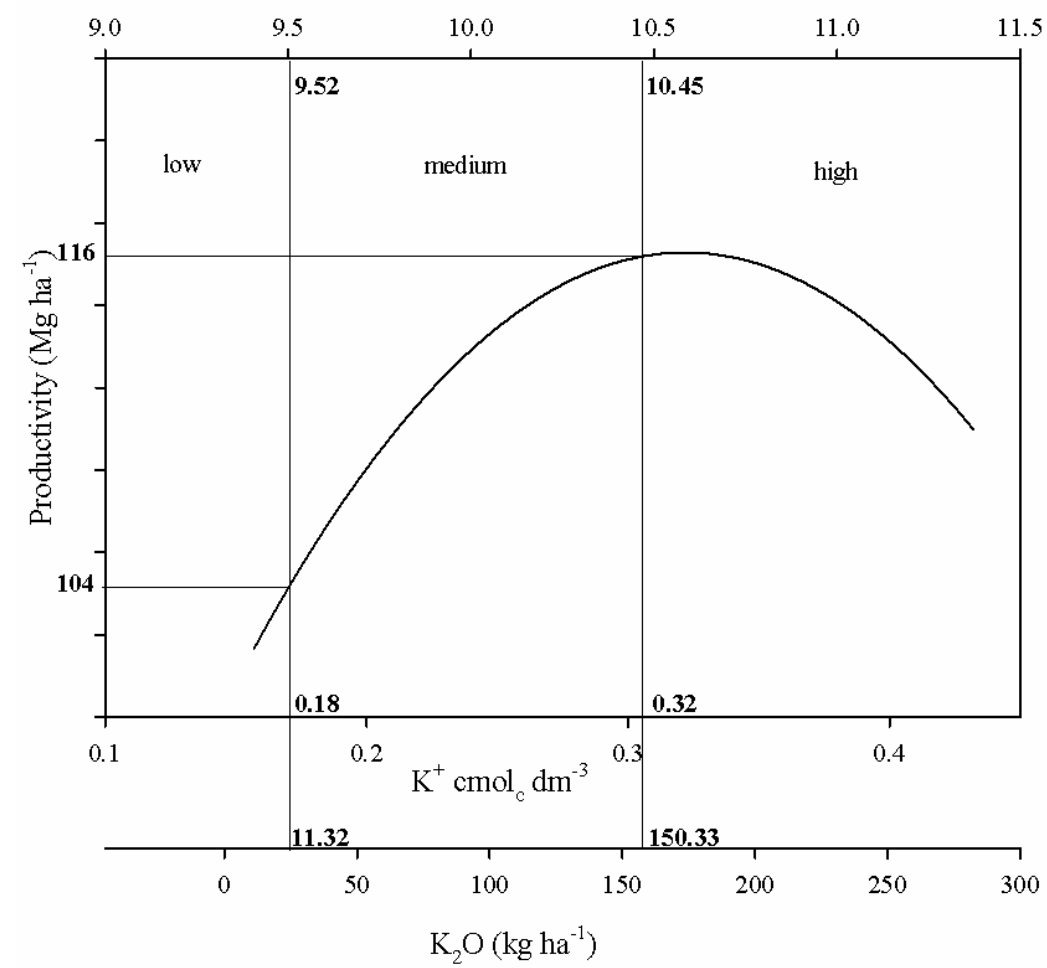

Fig 4. Critical levels of potassium in the soil and leaf at position $1($ leaf +1$)$ after four months of planting sugarcane, and dose of maximum agronomic efficiency.

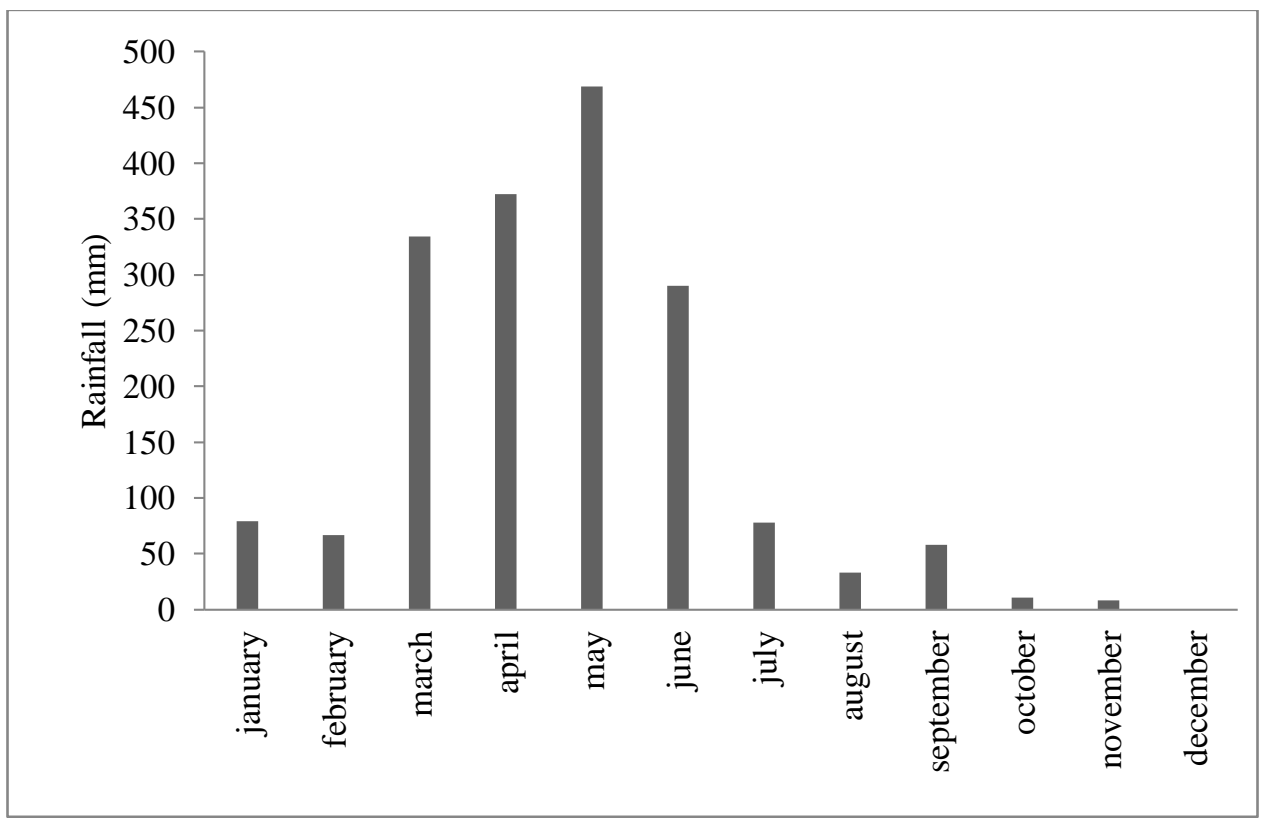

Fig 5. Distribution of monthly rainfall during the conduction of the experimental trial in 2016 at the municipality of Caaporã, Paraíba, Brazil. 
increase in culm yield represented a production increase of $13.7 \%$ (Figure $2 \mathrm{~A}$ ). Higher doses of $\mathrm{K}_{2} \mathrm{O}$ increased yield of total recoverable sugars on $7 \%$ in the highest dose of $\mathrm{K}$ applied (Figure 2B).

The increase in the agricultural productivity of sugarcane due to $\mathrm{K}$ application is described in literature (Uchôa et al., 2009; Almeida et al., 2015). However, the increase in technological quality of sugarcane due to $\mathrm{K}$ application is controversial. There are reports that found increase in sugar content (Watanabe et al., 2016). But some others researchers have found no positive effect of increasing $\mathrm{K}$ on sugar content (Mathew et al., 2004).

Almeida et al. (2015) reported that $K$ dose results in a productivity increase of $75 \mathrm{Mg} \mathrm{ha}^{-1}$ on variety SP81-3250. The dose of $65 \mathrm{~kg} \mathrm{ha}^{-1}$ of $\mathrm{K}_{2} \mathrm{O}$ promoted the acquisition of $88 \%$ of the maximum sugarcane crop yield.

Sugarcane varieties showed differing response capacities to the application of K. Uchôa et al. (2009) studied increase in the productivity of sugarcane as a function of the application of $\mathrm{K}$ in six varieties (RB72454, SP813250, SP91011, SP801816, RB867515 and RB855336). They observed yield variation from 55 to $186 \%$ in relation to the control treatment.

The $\mathrm{K}$ is essential in carrying the sugars from the source organs to the drains (Watanabe et al., 2017). Some studies have shown that $\mathrm{K}$ deficiency has resulted in increased sugar accumulation in the leaf and reduced translocation of photosynthates from the source organs to the drains (Hartt, 1970; Zörb et al., 2014). Wang et al. (2012) observed that Kdeficient cotton plants exported up to 3.5 times less sugars than plants sufficient in $\mathrm{K}$. In addition to their role in the transport of photosynthates, $\mathrm{K}$ also affects carbohydrate metabolism (Watanabe et al., 2017).

Watanabe et al. (2016) reported that the concentration of sucrose in sugarcane liquid extract varied in relation to the quantities of applied $\mathrm{K}$ and the period of plant sampling. When the evaluation was performed five months after the beginning of the experiment, the doses of $K$ increased sucrose concentration. However, in the other samplings $(7,9$ and 11 months), the treatments with the highest amounts of $\mathrm{K}$ had lower sucrose concentrations than control treatment.

Ashraf et al. (2009) reported that sugarcane juice quality was improved by application of $120 \mathrm{~kg} \mathrm{ha}^{-1}$ of $\mathrm{K}_{2} \mathrm{O}$. Furthermore, the percentages of soluble solids in the juice $(60 \%)$, percentage of sucrose in the juice (52\%) recoverable sugars (46\%) were increased. However, Otto et al. (2010) observed no effect on recoverable sugars with the increasing application of $K$, even $200 \mathrm{~kg} \mathrm{ha}^{-1}$ of $\mathrm{K}_{2} \mathrm{O}$. The authors found an increase in sugar production attributed to the increase in agricultural productivity.

\section{Electrical conductivity (EC) of the soil saturated paste as a function of $K$ applied to soil}

Data found for soil EC as a function of applied $\mathrm{K}$ doses showed an increasing linear regression (Figure 3 ). The EC in surface layer of soil increased $30 \%$ in the highest dose of $\mathrm{K}$ applied and in the subsurface layer increased $92 \%$.

In a review on the effects of salts on both soil and plant, Dias et al. (2016) reported that the tolerance limit for salinity in sugarcane plants is $1.7 \mathrm{dS} \mathrm{m}^{-1}$. This limit is close to the EC value found in this study for the application of a $250 \mathrm{~kg} \mathrm{ha}^{-1}$ of $\mathrm{K}_{2} \mathrm{O}$. The high solubility of the $\mathrm{KCl}$ fertilizer promoted a significant increase in the EC of the soil solution, interfering with the nutrition of sugarcane.

Low EC values in sandy soils may influence the initial development of sugarcane more than those in clay soils. Lira et al. (2018) studied the effects of salinity of irrigation water on very sandy soil ( $890 \mathrm{~g} \mathrm{~kg}^{-1}$ of sand) and observed that salinity negatively influenced all sugarcane growth variables such as stem height, number of tillers, leaf area, stem diameter and number of leaves. The authors reported also that irrigation with water salinity linearly reduced sugarcane agricultural yield and stem dry weight.

The decrease of productivity observed in this study may also be attributed to the effect of $\mathrm{Cl}$ toxicity because the chloride ion makes the $\mathrm{K}$ fertilizer be used as the source of $\mathrm{K}(\mathrm{KCl})$. However, the decrease of productivity may be better explained by the increase in the salinity of the rhizosphere in plants, caused by the increase of fertilizer. Otto et al. (2010) reported a decrease in the productivity of sugarcane after application of $150 \mathrm{~kg} \mathrm{ha}^{-1}$ of $\mathrm{K}_{2} \mathrm{O}$, using $\mathrm{KCl}$ as fertilizer source. Marques et al. (2014) also showed that $\mathrm{KCl}$ salinized the soil more than $\mathrm{K}_{2} \mathrm{SO}_{4}$.

$\mathrm{KCl}$ is a fertilizer with a high saline index (116). This index represents the ability of the fertilizer to increase the osmotic pressure of the soil solution as compared to sodium nitrate, which has a salinity of 100 (Marques et al., 2014). This feature may adversely affect the development of sugarcane. The salinity threshold which reduces productivity was $1.38 \mathrm{dS} \mathrm{m}^{-1}$ in the surface layer and $1.19 \mathrm{dS} \mathrm{m}^{-1}$ in subsurface.

\section{Critical levels of $K$ in the soil and sugarcane plant as a function of applied $K$}

Agricultural productivity as a function of increasing doses of $\mathrm{K}_{2} \mathrm{O}$ allowed calculation of maximum agronomic efficiency dose that was approximately $150 \mathrm{~kg} \mathrm{ha}^{-1}$ of $\mathrm{K}_{2} \mathrm{O}$ (Figure 4). This dose generated a maximum yield of $116 \mathrm{Mg} \mathrm{ha}^{-1}$ and allowed calculation of both soil $\left(0.32 \mathrm{cmol}_{\mathrm{c}} \mathrm{dm}^{-3}\right)$ and leaf $\mathrm{K}$ content $\left(10.45 \mathrm{~g} \mathrm{~kg}^{-1}\right)$. The dose that provided $90 \%$ of the maximum agronomic productivity (104 Mg ha ${ }^{-1}$ ) was of $11.32 \mathrm{~kg} \mathrm{ha}^{-1}$ of $\mathrm{K}_{2} \mathrm{O}$. Therefore, the critical levels of $\mathrm{K}$ in the soil and leaf of sugarcane were of $0.18 \mathrm{cmol}_{\mathrm{c}} \mathrm{dm}^{-3}$ and $9.52 \mathrm{~g} \mathrm{~kg}^{-1}$, respectively (Figure 4).

The calibration of diagnostic methods for soil fertility levels is crucial for the correction and fertilization management. Establishing reference values for nutrient availability and the amount of fertilizer to be applied in relation to the expected response of the crop are of fundamental importance for planting to be profitable (Calheiros et al., 2018).

Some studies have demonstrated different responses of sugarcane varieties to the application of increasing amounts of $\mathrm{K}$, in addition to differences between the doses of maximum efficiency and absorption capacity of K (Uchôa et al., 2009; Otto et al., 2010).

Doses of maximum efficiency between 94 and $165 \mathrm{~kg} \mathrm{ha}^{-1}$ of $\mathrm{K}_{2} \mathrm{O}$ were observed by Uchôa et al. (2009) for yield ranging from 31.9 and $56.9 \mathrm{Mg} \mathrm{ha}{ }^{-1}$, evaluating six varieties of 
sugarcane. Otto et al. (2010) determined a dose of maximum agronomic efficiency of $150 \mathrm{~kg} \mathrm{ha}^{-1} \mathrm{~K}_{2} \mathrm{O}$ for a productivity of $160 \mathrm{Mg} \mathrm{ha}^{-1}$.

The critical level of $\mathrm{K}$ in the soils of Northeast Brazil is currently $0.15 \mathrm{cmol}_{\mathrm{c}} \mathrm{dm}^{-3}$ and the recommended fertilization at this level is $60 \mathrm{~kg} \mathrm{ha}^{-1}$ of $\mathrm{K}_{2} \mathrm{O}$ (Cavalcanti et al., 2008). However, this value was recommended for varieties that have agricultural productivity expectations between 50 and $75 \mathrm{Mg} \mathrm{ha}{ }^{-1}$ (Cavalcanti et al., 2008). The critical level obtained in this study was $0.18 \mathrm{cmol}_{\mathrm{c}} \mathrm{dm}^{-3}$ for agricultural productivity of $104 \mathrm{Mg}$ ha 1

There are several suggestions for critical levels of $K$ in the soil described in literature (Orlando Filho et al., 1981; Chalita, 1991; Cavalcanti et al., 2008). Calheiros et al. (2018) reported that the appropriate nutrient content for each production environment should be calibrated according to regional specificity due to nutritional standards described in the literature having been obtained in locations with varying soil, climate and variety specificities, which used in other settings and do not provide accurate diagnoses of nutritional status.

\section{Materials and methods}

\section{Characterization of the study site}

The experiment was conducted in the municipality of Caaporã, Paraíba, Brazil, at the geographical coordinates 7030'30.194324" South Latitude and 34952'33.169375" West Longitude. The municipality is located at $37 \mathrm{~m}$ above sea level and has an Am climate, according to Köppen-Geigerem climatic classification (Alvares et al., 2013).

The soil for cultivation of the sugarcane was classified as Oxisol (Kandic) (Soil Survey Staff, 2014). Before the cultivation of sugarcane, five samples were collected from the testing area to characterize the soil at depths of 0.0-0.25 and 0.25-0.50 m to compose a composite sample and chemical analyzes for fertility evaluation $\left[\mathrm{pH}_{\text {water }}, \mathrm{P}, \mathrm{Na}^{+}, \mathrm{K}^{+}, \mathrm{Ca}^{2+}, \mathrm{Mg}^{2+}, \mathrm{Al}^{3+}\right.$ and $(\mathrm{H}+\mathrm{Al})]$. Our study also determined levels of $\mathrm{Zn}, \mathrm{Cu}, \mathrm{Mn}, \mathrm{Fe}$ and total organic C (TOC). Physically, the soil was characterized by granulometry, particle density, soil density and total porosity. All analyzes were performed according to procedures reported by Teixeira et al. (2017) (Table 1).

The total rainfall during the experimental trial was $1,800 \mathrm{~mm}$, distributed throughout the growing period of the sugarcane (Figure 5).

\section{Experimental procedures}

The experiment was set up in randomized blocks and used the RB992506 sugarcane variety. $\mathrm{K}$ was applied in the following amounts: 0 ; 21.0; 41.5; 83.0; 166.0; and $207.5 \mathrm{~kg} \mathrm{ha}^{-1}$ corresponded to approximately the following doses of $\mathrm{K}_{2} \mathrm{O}: 0$; 25 ; $50 ; 100 ; 200$; and $250 \mathrm{~kg} \mathrm{ha}^{-1}$. The experiment was performed in four replicates, totaling 24 experimental plots.

The plots were composed of six double furrows each measuring $10.0 \mathrm{~m}$ in length with $1.5 \mathrm{~m}$ spacing between the double furrows and $0.9 \mathrm{~m}$ between each single furrow, corresponding to a total area of $72 \mathrm{~m}^{2}$. The useful area was composed of four central furrows, leaving $1.0 \mathrm{~m}$ on each side, totaling $37.6 \mathrm{~m}^{2}$.

Soil preparation was carried out with chemical control of spontaneous plants, subsoiling, plowing, harrowing and furrowing. The sugarcane was planted by distributing culms into the furrows to a depth of $0.25 \mathrm{~m}$. At planting, approximately $18 \mathrm{Mg} \mathrm{ha}{ }^{-1}$ of culms was distributed, with subsequent sectioning to obtain 24 gems per linear meter, on average. Fungicide $\left(0.5 \mathrm{~L} \mathrm{ha}{ }^{-1}\right)$, nematicide $\left(5 \mathrm{~L} \mathrm{ha}^{-1}\right)$ and termiticide $\left(0.2 \mathrm{~kg} \mathrm{ha}^{-1}\right)$ were each applied to the culms at planting prior to closing the furrows.

The soil was corrected with $1.1 \mathrm{Mg} \mathrm{ha}^{-1}$ of dolomitic limestone with $85 \%$ total relative neutralizing power (TRNP). A $1.0 \mathrm{Mg}$ ha

${ }^{1}$ of gypsum was applied to the soil due to low Ca content in subsurface (Tiecher et al., 2018). The need for liming was calculated to raise base saturation to $70 \%$ (Cavalcanti et al., 2008). The correctives were applied throughout the total experimental area to a depth of $0.25 \mathrm{~m}$.

Foundation fertilization was carried out with $60 \mathrm{~kg} \mathrm{ha}^{-1}$ of $\mathrm{N}$ as urea, $200 \mathrm{~g} \mathrm{ha}^{-1}$ of Mo in the form of sodium molybdate (Santos et al., 2018) and $180 \mathrm{~kg} \mathrm{ha}^{-1}$ of $\mathrm{P}_{2} \mathrm{O}_{5}\left(\approx 78.6 \mathrm{~kg} \mathrm{ha}^{-1}\right.$ of P) with triple superphosphate (Simões Neto et al., 2015). The $K$ was applied using potassium chloride as the source. In addition, we applied $2.6 \mathrm{~kg} \mathrm{ha}^{-1}$ of $\mathrm{Cu}, 4 \mathrm{~kg} \mathrm{ha}^{-1}$ of $\mathrm{Zn}, 5.2 \mathrm{~kg}$ ha ${ }^{1}$ of $\mathrm{Mn}$ as sulfate and $2.0 \mathrm{~L} \mathrm{ha}^{-1}$ of $\mathrm{B}$ as sodium borate (Cavalcanti et al., 2008).

\section{Soil measurements}

Soil sampling was performed 30 days after the application of $\mathrm{K}$ at $0.25 \mathrm{~m}$ from the center of furrow to determine available $\mathrm{K}$ content. The composite soil sample was comprised of a random collection of three simple samples in the useful area of each plot. The samples were collected in the layers of 0.0-0.25 and $0.25-0.50 \mathrm{~m}$ deep. $\mathrm{K}$ content was extracted from the soil with a Mehlich-1 extractor at the ratio $(1: 10)$ to the base volume (soil:solution). The dosage of $\mathrm{K}$ content was performed in a flame spectrophotometer (Teixeira et al., 2017).

EC determination was performed with approximately $300 \mathrm{~g}$ of soil from each sample. The soils of the samples were moistened with deionized water until they showed a shiny surface appearance (saturated paste) and were then allowed to stand overnight. Subsequently, the saturated pastes were placed in funnels with filter paper and suctioned with vacuum pump to collect the paste extract. EC was determined in a conductivity meter (Teixeira et al., 2017).

\section{Plant measurements}

Sampling of the sugarcane to determine the $\mathrm{K}$ content was performed on the leaf at position $1($ leaf +1$)$ at four months after planting in the middle third of the plant, with the central vein removed. The composite sample was formed from 15 leaves in the useful plot. The leaves were dried in a forced air ventilation oven at $65 \stackrel{\circ}{\circ}$ to a constant weight and milled. $\mathrm{K}$ mineralization in the plant tissue was performed by nitroperchloric digestion, weighing $500 \mathrm{mg}$ of the plant material. The dosage of the $\mathrm{K}$ content was performed in a flame spectrophotometer (Teixeira et al., 2017). 
Agricultural productivity ( $\mathrm{Mg} \mathrm{ha}{ }^{-1}$ ) was evaluated by harvesting all plants in each plot. After the harvest, the plants were weighed in a dynamometer and values per hectare were estimated. Technological quality was evaluated by the total recoverable sugar $\left(\mathrm{kg} \mathrm{Mg}^{-1}\right)$, according to Fernandes (2003).

\section{Critical levels of $K$}

From the data found for agricultural productivity, available $\mathrm{K}$ content in the soil $\left(\mathrm{cmol}_{\mathrm{c}} \mathrm{dm}^{-3}\right.$ ) and $\mathrm{K}$ content in the plant $(\mathrm{g} \mathrm{kg}$ ${ }^{1}$ ), regression analysis was then performed for the $\mathrm{K}$ applied to the soil $\left(\mathrm{kg} \mathrm{ha}^{-1}\right)$. The critical level of $\mathrm{K}$ in soil $\left(\mathrm{cmol}_{\mathrm{c}} \mathrm{dm}^{-3}\right)$ and the critical level of $\mathrm{K}$ in the plant $\left(\mathrm{g} \mathrm{kg}^{-1}\right)$ was considered as the dose-equivalent $\mathrm{K}$ content $\left(\mathrm{kg} \mathrm{ha}^{-1}\right)$, which provided $90 \%$ of maximum yield ( $\mathrm{Mg} \mathrm{ha}^{-1}$ ) (Reuter and Robinson, 1988).

\section{Statistical procedures}

The experimental data were analyzed after checking their normal distribution and homoscedasticity of variance. Variance analysis (ANOVA) was applied, using an $F$ test criterion $(p<0.05)$. Subsequently, the selected models were those with significance for the coefficients of the parameters of highest degree by $t$ test $(p<0.05)$, concomitantly with largest coefficient of determination $\left(R^{2}\right)$.

\section{Conclusions}

The higher amounts of $\mathrm{K}$ increased agricultural productivity and technological quality of the sugarcane variety RB992506. The dose of maximum agronomic efficiency was $150 \mathrm{~kg} \mathrm{ha}^{-1}$ of $\mathrm{K}_{2} \mathrm{O}$ and the maximum productivity was $116 \mathrm{Mg} \mathrm{ha}^{-1}$. From the dose of $150 \mathrm{~kg} \mathrm{ha}^{-1}$ of $\mathrm{K}_{2} \mathrm{O}$ there was a decrease in agricultural productivity due to the rising salinity of the soil solution, with a salt boundary of $1.38 \mathrm{dS} \mathrm{m}^{-1}$ in the surface layer and $1.19 \mathrm{dS} \mathrm{m}$ 1 in the subsurface. The soil and plant critical levels were $0.18 \mathrm{cmol}_{\mathrm{c}} \mathrm{dm}^{-3}$ and $9.53 \mathrm{~g} \mathrm{~kg}^{-1}$, respectively, suggesting that these critical levels and limits can be used to evaluate the fertility of sandy soils cultivated with sugarcane in Northeast Brazil.

\section{Acknowledgement}

The authors would like to thank the National Council for Scientific and Technological Development (CNPq) for granting scholarships and to scholars and volunteers for their help in conducting the experiment and collecting data.

\section{References}

Ahmad I, Maathuis F (2014) Cellular and tissue distribution of potassium: physiological relevance, mechanisms and regulation. J Plant Physiol. 171:708-714.

Almeida HJ, Cruz FJR, Pancelli MA, Flores RA, Vasconcelos RL, Prado RM (2015) Decreased potassium fertilization in sugarcane ratoons grown under straw in different soils. Aust J Crop Sci. 9:596-604.
Anschütz U, Becker D, Shabala S (2014) Going beyond nutrition: regulation of potassium homoeostasis as a common denominator of plant adaptive responses to environment. J Plant Physiol. 171:670-687.

Ashraf M, Rahmatullah Ahmad R, Afzal M, Tahir MA, Kanwal S, Maqsood MA (2009) Potassium and silicon improve yield and juice quality in sugarcane (Saccharum officinarum L.) under salt stress. J Agron Crop Sci. 195:284-291.

Bordonal RO, Carvalho JLN, Lal R, Figueiredo EB, Oliveira BG, La Scala N (2018) Sustainability of sugarcane production in Brazil. A riview. Agro Sustain Dev. 28:13-23.

Calheiros LCS, Freire FJ, Moura Filho G, Oliveira ECA, Moura AB, Costa JVT, Cruz FJR, Santos AS, Rezende JS (2018) Assessment of nutrient balance in sugarcane using DRIS and CND methods. J Agric Sci. 10:164-179.

Cavalcanti FJA, Santos JCP, Pereira JR, Leite JP, Silva MCL, Freire FJ, Silva DJ, Sousa AR, Messias AS, Faria CMB, Burgos N, Lima Júnior MA, Gomes RU, Cavalcanti AC, Lima JFWF (2008) Recomendações de adubação para o estado de Pernambuco. Instituto Agronômico de Pernambuco, Recife.

Chalita R (1991) Calibraçao da adubação potássica através da análise química do solo para a cultura da cana-de-açúcar. 88p. Dissertation (Masters degree). Universidade de São Paulo, Escola Superior de Agricultura "Luiz de Queiroz", Piracicaba.

Dias NS, Blanco FF, Souza ER, Ferreira JFS, Sousa Neto OM, Queiroz ISR (2016) Efeitos dos sais no solo e tolerância das culturas à salinidade. In: Gheyi HR, Dias NS, Lacerda CF, Gomes Filho E (eds) Manejo da salinidade na agricultura: estudos básicos e aplicados. Instituto Nacional de Ciência e Tecnologia, Fortaleza.

Fernandes AC (2003) Cálculos na agroindústria da cana-deaçúcar, 2rd edn. STAB, Piracicaba. de-açúcar. 2. ed. Piracicaba: EME/STAB, 2003.

Food and Agriculture Organization - FAO (2012) Faostat. Available in: <http://faostat.org/>. Accessed in: 21/12/2012.

Hartt CE (1970) Effect potassium deficiency upon translocation of ${ }^{14} \mathrm{C}$ in detached blades of sugarcane. Plant Physiol. 45:183187.

Lira RM, Silva EFF, Simões Neto DE, Santos Júnior JA, Lima BLC, Silva JS (2018) Growth and yield of sugarcane irrigated with brackish water and leaching fractions. R Bras Eng Agr Amb. 22:170-175.

McLean EO (1976) Exchangeable K levels for maximum crop yields on soils of different cation exchange capacities. Commun Soil Sci Plant Anal. 7:823-838.

Marques DJ, Broetto F, Ferreira MM, Lobato AKS, Ávila FW, Pereira FJ (2014) Effect of potassium sources on the antioxidant activity of eggplant. Rev Bras Cienc Solo. 38:18361842.

Mathew T, Kurian TM, George B, Cherian S, Kuriakose JM, Sreekumar K, Jayakumar G (2004) Effect of time and mode of application of potassium on the growth, yield and quality of sugarcane ratoon. Sugar Tech. 6:81-83.

Mengel K, Kirkby EA (2001) Principles of plant nutrition. Kluwer Academic Publisher, Dordrecht.

Orlando Filho J, Zambello Júnior E, Rodella AA (1981) Calibração de potássio no solo e recomendação de adubação para a canade-açúcar. Brasil Açucareiro. 97:18-24. 
Otto R, Vitti GC, Luz PHC (2010) Manejo da adubação potássica na cultura da cana-de-açúcar. Rev Bras Cienc Solo. 34:11371145.

Pancelli MA, Prado RM, Flores RA, Almeida HJ, Moda LR, Souza Junior JP (2015) Growth, yield and nutrition of sugarcane ratoon as affected by potassium in a mechanized harvesting system. Aust J Crop Sci. 9:915-924.

Reuter DJ, Robinson JB (1988) Plant analysis: an interpretation manual. Inkata, Melbourne.

Santos RL, Freire FJ, Oliveira ECA, Simões Neto DE, Medeiros MRFA, Bezerra PC, Moura MJA, Barbosa JA, Lopes NRC, Santos NL (2018) Productivity and technological quality of sugarcane under fertilization of nitrogen and molybdenum. J Soil Sci Plant Nutr. 18:1002-1020.

Schultz N, Lima E, Pereira MG, Zonta E (2010) Efeito residual da adubação da cana-planta e da adubação nitrogenada e potássica na cana-soca colhidas com e sem a queima da palhada. Rev Bras Cienc Solo. 34:811-820.

Simões Neto DE, Oliveira AC, Freire FJ, Freire MBGS, Oliveira ECA, Rocha AT (2015) Adubação fosfatada para cana-de-açúcar em solos representativos para o cultivo da espécies no nordeste brasileiro. Pesqui Agropecu Bras. 50:73-81.

Soil Survey Staff (2014) Keys to soil taxonomy. Natural Resources Conservation Service, Washington (DC).

Sousa JS, Lima JCL, Martinez HEP, Alvarez V. VH (2018) Relationship between coffe leaf analysis and soil chemical analysis. Rev Bras Cienc Solo. 42:e0170109.
Teixeira PC, Donagema GK, Fondana A, Teixeira WG (2017) Manual de métodos de análise de solo. Embrapa, Rio de Janeiro.

Tiecher T, Pias OHC, Bayer C, Martins AP, Denardin LGO, Anghinoni I (2018) Crop response to gypsum application to subtropical soils under no-till in Brazil: a systematic review. Rev Bras Cienc Solo. 42:e0170025

Uchôa SCP, Alves Júnior HO, Alves JMA, Melo VF, Ferreira GB (2009) Resposta de seis variedades de cana-de-açúcar a doses de potássio em ecossistema de cerrado de Roraima. Rev Cienc Agron. 40:505-513.

Wang N, Hua H, Eneji AE, Li Z, Duan L, Tian X (2012) Genotypic variations in photosynthetic and physiological adjustment to potassium deficiency in cotton (Gossypium hirsutum). J Photoch Photobio B. 110:1-8.

Watanabe K, Fukuzawa Y, Kawasaki SI, Ueno M, Kawamitsu Y (2016) Effects of potassium chloride and potassium sulfate on sucrose concentration in sugarcane juice under pot conditions. Sugar Tech. 18:258-265.

Watanabe K, Tominaga J, Yabuta S, Takaragawa H, Suwa R, Ueno $M$, Kawamitsu $Y$ (2017) Effects of different kinds of potassium and chloridies salts on sugarcane quality and photosynthesis. Sugar Tech. 19:378-385.

Zörb C, Senbayram M, Peiter E (2014) Potassium in agriculture status and perspectives. J Plant Physiol. 171:656-669. 